Sonderdruck aus Zeitschrift für Tierzüchtung und Züchtungsbiologie

Bd. 98 (1981), H. 4, S. 312-318

VERLAG PAUL PAREY - HAMBURG 1 - SPITALERSTRASSE 12

Rechte, auch die der Übersetzung, des Nachdrucks, der photomechanischen Wiedergabe und der Speicherung in Datenverarbeitungsanlagen, vorbehalten, (1) 1981 Verlag Paul Parey, Hamburg und Berlin

Faculté de médécine vétérinaire (U. Lg.), Bruxelles, Belgium

\title{
Plasma insulin level in double-muscled and conventional bulls during the first year of life ${ }^{1}$
}

\author{
By C. Michaux, J. F. Beckers, M. de Fonseca and R. Hanset
}

Ms. received 15.11.1980

\section{Introduction}

Insulin is an anabolizing hormone, stimulating the growth of cartilage (DAUGHADAY et al. 1975), the protein synthesis in muscle (MUNRO 1964; Wool et al. 1968) and triglycerides storage in the adipose tissue owing to its lipogenic and antilipolytic properties (RANDLE et al. 1966).

In a previous work (Michaux et al. 1980) we observed that double-muscled bulls have lower or not different plasma GH level after 4 months of age. Several relations exist between insulin and GH (Reviews by DAGHADAY and KIPNIS 1966; HaLL and LuFt 1974; VAN WYCK et al. 1974; TURNER and MUNDAY 1976; SizONENKO 1978). GH has insulinlike effects mediated by the somatomedins on body growth and protein synthesis and insulin antagonistic effect owing to its lipolytic action. Insulin is required for the full anabolic effect of GH. Plasma levels of insulin are low in patients with hypopituitarism. Wether insulin has any direct physiological effect on the regulation of cartilage metabolism and linear growth is not clearly established (Review by LeBovitz and EIsenuARTH 1975) but Daughaday et al. (1976) showed that insulin shares with GH the regulation of somatomedin release by the liver. The present study has been undertaken because double-muscling is characterized not only by a muscular hypertrophy but also by a drastic reduction in adipose tissue (ANSAY and HANSET 1979).

\section{Material and methods}

The bull, their management and the experimental design were described previously (Michaux et al. 1981). Briefly they are conventional and double-muscled bulls sired by A.I. bulls of the Belgian Blue breed progeny-tested in 1978-79. Blood samples were taken at the jugular vein at $d 80,131,227$ and 370 on average, cooled and centrifuged, and plasma was kept at $-15^{\circ} \mathrm{C}$ until assayed.

Plasma insulin (in duplicate) was measured by radio-immunoassay (Agosin 1979; Agosin et al. 1981). Bovine insulin (Sigma chemical Co., $24.3 \mathrm{UI} / \mathrm{mg}$ ) was used for preparation of the standard, for labelling and for the production of the antiserum.

Antiserum was obtained after immunization of guinea pigs. Labelling of bovine insulin with $^{125}$ I was performed according to the method of THORELL and JoHANSON (1971) using

'This work is supported by "Institut pour l'encouragement de la Recherche Scientifique dans l'Industrie et l'Agriculture" (I. R.S.I. A.).

U.S. Copyright Clearance Center Code Statement: 0044-3581/81/9804-0312 \$2.50/0

Z. Tierzüchtg. Züchtgsbiol. 98 (1981) 312-318

(c) 1981 Verlag Paul Parey, Hamburg und Berlin ISSN 0044-3581/InterCode: ZTZBAS 
the Lactoperoxydase. The bound insulin was separated using an antiserum anti guinea-pig $\gamma-$ globulins obtained from rabbit, coupled to cellulose activated by cyanogen bromide (DASP system) (AxEN et al. 1967).

Owing to the skweness of the distribution of insulin plasma concentrations, the means of each determination between conventional and double-muscled bulls have been compared using the Mann and Whitney test and the correlations have been estimated by the Spearman rank correlation coefficient.

\section{Results}

Plasma insulin level is significantly lower in double-muscled bulls at all ages studied (Table 1). Insulin level decreases significantly in conventionals from 80 to $131 \mathrm{~d}$ of age $(\mathrm{P}<1 \%)$ and in double-muscled from 227 to $370 \mathrm{~d}$ of age $(\mathrm{P}<5 \%)$ (Table 1$)$.

These age related changes are depicted in figure 1. The means and standard deviations for several growth traits (body weight and wither height at 7 , 10 and 12 months, average daily gain from 7 to 12 months), for daily feed intake and feed efficiency from 7 to 12 months, for the $7^{\text {th }}$ rib cut components (lean, fat and bone percent) have been reported previously as well as the differences between the two types of bulls for these traits (Michaux et al. 1981). The correlation coefficients between concentrations of plasma insulin and these traits have been computed for each type of bulls (Table 2). The correlation coefficients between plasma insulin and body weight, wither height, average daily gain, daily feed intake are most of ten positive and significantly different from zero in double-muscled bulls.

Plasma insulin concentration in conventional and double-muscled bulls during the first year of age

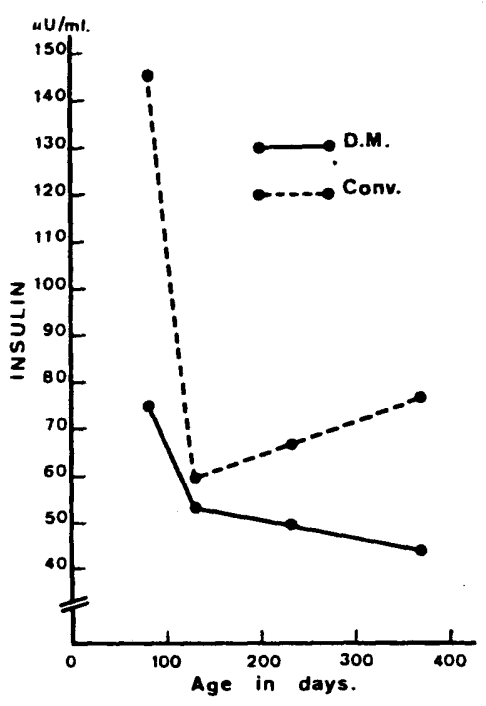

\section{Table 1}

Plasma insulin level in conventional and double-muscled bulls $(\mu \mathrm{U} / \mathrm{ml})$ at 80 days (I1), 131 days (I2), 227 Days (I3) and 370 days (I4) of age in average ( $n=$ number of bulls)

\begin{tabular}{|c|c|c|c|c|c|c|c|c|c|}
\hline & \multicolumn{4}{|c|}{ CONVENTION:ALS } & \multicolumn{5}{|c|}{ DOUELE-MUSCLED } \\
\hline & $n$ & $\bar{x}$ & $s$ & $\mathrm{P}$ age & $n$ & $\bar{x}$ & $s$ & $F$ age & P type \\
\hline I1 & 30 & 145.1 & 90.9 & & 75 & 75.9 & 62.4 & & *** \\
\hline I2 & 91 & 59.5 & 23.9 & & 73 & 53.2 & 34.2 & N.S. & ** \\
\hline I3 & 88 & 66.8 & 31.6 & N.S. & 71 & 49.8 & 15.7 & N.S. & $* * *$ \\
\hline I4 & 86 & 76.3 & 43.3 & M.S. & 68 & 44.4 & 16.2 & & $* * *$ \\
\hline \multicolumn{10}{|c|}{ 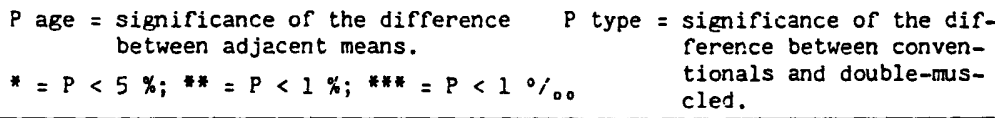 } \\
\hline
\end{tabular}


The correlation coefficients between the successive insulin levels are generally positive and are significant in the two types of bulls between determinations at $131 \mathrm{~d}$ and $227 \mathrm{~d}$ (Table 3). The correlations between plasma level of insulin and of $\mathrm{GH}$ are low and negative (Table 4).

\section{Discussion}

In growing cattle, Young et al. (1970), TrenkLE and Irvin (1970), TrenkLe (1970), Irvin and TRENKLE (1971) did not find a significant relationship between plasma insulin level and age while TRENKLE and TOPEL (1978) observed that insulin was positively associated $(\mathrm{P}<$ $1 \%$ ) with age or body weight in the postweaning period. TRENKLE (1970) found that insulin level increases with length of time cattle were fed grain.

Insulin increases after feeding (MC ATEE and TRENKLE 1971). In this study, the bulls were fed at libitum and the blood sampling made irrespective of meal-time and type of the bulls. On the other hand, level of feeding (ad libitum vs limited) had no significant effect on plasma insulin level determined in the postabsorptive state (TRENKLE and TOPEL 1978), but in obese rodents hyperinsulinemia is associated in various degrees, depending on genetic type of obesity, with hyperphagia (Review by YoRK 1979). Now double-muscled bulls exhibit a smaller feed intake ( $\mathrm{P}<1 \%$, HaNset et al. 1979).

TRENKLE and TOPEL (1978) found significant negative correlations between insulin plasma level and carcass muscle. Double-muscled which show muscular hypertrophy and a greater daily protein deposit, have lower insulinemia. In each type, the correlation coefficients between insulin concentration and lean percent are low and tend to be negative in double-muscled (Table 2).

Plasma insulin concentration is positively related to the fatness of the carcass and to the lipid percentage in muscle (TRENKLE and IRVIN 1970; TRENKLE and TOPEL 1978). The lower insulin level in double-muscled agrees with their reduced fatness. The correlations between insulin level and fat percent in the $7^{\text {th }}$ rib cut are low and mostly positive in the two types (Table 2).

No differences in insulin circulating level have been found in cattle differing in body composition such as steers and bulls (GALBRAITH et al. 1978) and such as Angus, Hereford and Shorthorn animals (lRvin and TRENKLE 1971).

Insulin promotes both ponderal and linear growth (SALTER and BEST 1953), insulin level is decreased in idiopathic short stature in man (SIZONENKO 1978). Concentration of plasma insulin is positively associated $(\mathrm{P}<1 \%$ ) with body weight in steers (TRENKLE and ToPEL 1978). Double-muscled have slightly reduced body weight and wither height (Michaux et al. 1981).

In this context, double-muscling may be compared (i) to Pietrain pigs which have lower insulin level than Large White (RogDAKIs et al. 1979) and (ii) in an other way, to the genetic obese rodents which show hyperinsulinemia.

A possible explanation of the obesity in rodents is an enzyme defect acting, according to the type and severity of obesity, on one or several organs such as hypothalamus, pancreas and muscle with consequences of hyperphagia, hypersecretion of insulin and reduced uptake or utilization of glucose (Review by YORK 1979). In diabetes mellitus, there is insufficient production or increased elimination of insulin and consequently a reduced glucose utilization expressed by a low glucose tolerance.

The Pietrain pigs have, relative to fatty breeds, a lower insulin secreting ability as shown by their response to tolbutamide and glucose injection and a lower sensitivity to the antilipolytic action of insulin which account partly for their reduced fatness (GREGORY et al. 1977; WOOD et al. 1977). 
Having found that, at 12 and 20 months of age, Friesians have higher insulin secreting ability $(P \leq 5 \%)$ anc smaller percentage of dissectible fat from the empty body $(P<5 \%)$ than Hereford, GREGORY et al. (1980) concluded that different insulin secreting ability in cattle is not related to differences in fatness between animals as it is the case in pig. But the low insulin status of Pietrain pigs would not be confined to the pancreatic function because they have lower level of somatomedin which has an important non-suppressible insulinlike activity (GREGORY et al. 1977).

In relation to the lower insulin level found in double-muscled cattle other physiological characturistics have been observed in these animals such as lower feed intake and glycemia (Holmes and Robinson 1970; Konecka et al. 1979) as has been also found in Pietrain pigs (GREGORY et al. 1979). In the light of the above described genetic variations of insulin metabolism it appears that the relative hypoinsulinemia of double-muscling could be due to a primary reduced synthesis or secretion, or could be a response to other physiological peculiarities.

\section{Summary}

Concentration of plasma insulin has been determined by radioimmunoassay in conventional and double-muscled bulls at 80 (I1), 131 (I2), 227 (I3) and 370 (I4) d of age. Double-muscled bulls have lower plasma levels of insulin at all ages studied, which is consistent with the reduced fatty tissue of double-muscling.

The correlations between insulin level and growth traits, estimated separately for each type of bulls, are low and most often positive and significant in double-muscled. Insulin level tends to be negatively correlated with the lean percent from the $7^{\text {th }}$ rib cut. The correlations between the successive insulin levels are generally positive. The correlations between the concentration of insulin and of $\mathrm{GH}$ are low and negative.

\section{Résumé}

Taux de l'insuline plasmatique chez des taureaux conventionnels et culards pendant la première année de la vie

L'insuline plasmatique a été dosée par radioimmunoessai chez des taureaux conventionnels et culards aux àges moyens de 80 (I 1), 131 (I2), 227 (I3) et 370 (I4) jours. Les culards ont des taux inférieurs à tous les âges étudiés, cette observation concorde avec leur faible développement adipeux.

Les corrélations, séparément pour chacun des types, entre l'insuline plasmatique et les caractères de croissance sont faibles et plus souvent positives et significatives chez les culards. Les corrélations entre le taux d'insuline et le pourcentage de muscles du jeme monocostal sont faibles et négatives. Les corrélations entre les taux successifs d'insuline sont généralement positives. Les taux plasmatiques d'insuline et de GH sont faiblement et négativement corrélés entre eux.

\section{Resumen}

\section{Nivel plasmático de insulina en toritos normales y tales de doble musculatura} durante el primer año de vida

En toritos normales y tales de doble musculatura los niveles de insulina plasmática fueron medidos mediante la radio-inmunoessai a las edades medias de 80 (I1), 131 (I2), 227 (I3) y 370 (I4) dias. Los de doble musculatura tienen niveles inferiores a todas edades, concordando esta observación con su reducido crecimiento adiposo. Las correlaciones entre insulina plasmática y características de crecimiento, determinadas separadamente para los tipos, son bajas y más frecuentemente positivas y significativas en los animales de doble musculatura. Las correlaciones entre tasa de insulina y porcentaje del tejido muscular en la $7^{2}$ costilla son débilmente negativas.

Las correlaciones entre las tasas sucesivas de insulina generalmente son positivas. Las tasas plasmáticas de insulina y de GH son débil y negativamente correladas entre sí.

\section{Zusammenfassung}

Plasmainsulinspiegel in Doppellendern und konventionellen Bullen wäbrend des 1. Lebensjabres

Der Plasmainsulinkonzentration wurde mit Hilfe von Radio-Immunassay in konventionellen und Doppellenderstieren bei 80 (I1), 131 (12), 227 (13) und 370 (I4) Tagen Alter bestimmt. Doppellender 
haben niedrigere Plasmainsulinspiegel in allen untersuchten Altersstufen. Diese Beobachtung ist konsistent mit dem verminderten Fettanteil bei Doppellendern. Die Korrelationen zwischen Insulin und Wachstumshormonspiegel, die für jeden Typ bestimmt wurden, sind niedrig, meistens positiv und signifikant in Doppellendern. Insulinspiegel scheinen mit dem Fleischanteil des 7. Rippenstückes negativ korreliert zu sein. Die Korrelationen zwischen aufeinander folgenden Insulınspiegeln sind im allgemeinen positiv. Die Korrelation zwischen Insulinkonzentration und jener von $\mathrm{GH}$ sind niedrig und negativ.

\section{Literature}

Agosin, E. 1979: Dosage radioimmunologique de l'insuline ovine et bovine. Memoire (roneotype).

Agosin, E.; Beckers, J. F.; Ectors, F., 1981: Dosage radioimmunologique des insulines ovine et bovine. Ann. Méd. Vét. 125, (submitted for publication).

ANSAY, M.; HANSET, R., 1979: Anatomical, physiological and biochemical differences between conventional and ciouble-muscled cattle in the Belgian Blue and White breed. Livest. Prod. Sci. 6, 5.

AXEN, R.; Porath, J.; ERnBaCK, S., 1967: Chemical coupling of peptides and proteins to polysaccharides by means of cyanogen halides. Nature, 214, 1302.

DaughadaY, W.H.; KIPNIS, D.M., 1966: The growth-promoting and anti-insulin actions of somatotropin. Rec. Progr. Horm. Res. 22, 49.

Daughaday, W. H.; Herington, A.C.; Phillips, L.S., 1975: The regulation of growth by endocrines. Ann. Rev. Physiol. 37, 211.

Daughaday, W. H.; Phillips, L.S.; Mueller, M.C., 1976: The effects of insulin and growth hormone on the release of somatomedin by the isolated rat liver. Endocrinol. 98, 1214.

Galbraith, H.; Dempster, D. G.; Miller, T. B., 1978: A note on the effect of castration on the growth performance and concentrations of some blood metabolites and hormones in British Friesian male cattle. Anim. Prod. 26, 339.

GREGORY, N. G.; LOVELL, R. D. L.; WOOD, J. D.; L1STER, D., 1977: Insulin secreting ability in Pietrain and Large White pigs. J. Agric. Sci. 89, 407.

Gregory, N. G.; Truscotr, T. G.; WOOD, J. D., 1980: Insulin secreting ability in relation to fatness in cattle. Proc. Nutr. Soc. $39,7 \mathrm{~A}$.

HaLL, K.; Luft, R., 1974: Growth hormone and somatomedin. Adv. Metabolic disorders 7, 1.

Hanset, R.; Stasse, A.; Michaux, C., 1979: Feed intake and feed efficiency in double-muscled and conventional cattle. Z. Tierzüchtg. Züchtungsbiol. 96, 260.

Holmes, J. H. G., Roвinson, D. W., 1970: Hereditary muscular hypertrophy in the bovine metabolic response to nutritional stress. J. Anim Sci. 31, 776.

IRviN, R.; TRENKLE, A., (1971): Influence of age, breed and sex on plasma hormones in cattle. J. Anim. Sci. 32, 292.

Konecka, A. M.; Kolataj, A.; Dziewiecki, C.; Swiergiel, A., 1978-79: Physiological aspects of muscular hypertrophy in cattle.

II. The activity of LDH and levels of L. Lactic acid and glucose in the blood plasma. Z. Tierzüchtg. Züchtungsbiol. 95, 227.

Lebovitz, H. E.; EISENBARTH, G. S., 1975: Hormonal regulation of cartilage growth and metabolism. Vitamins and Hormones 33, 575.

MCATEE, J. W.; TRENKLE, A., 1971: Metabolic regulation of plasma insulin levels in cattle. J. Anim. Sci. 33, 438.

Michaux, C.; HANSET, R., 1981 : Sexual development of double-muscled and conventional bulls.

2. Plasma testosterone and luteinizing hormone (LH) levels. Z. Tierzüchtg. Züchtungsbiol. 98, 38.

Michaux, C.; Van Sichem-Reynaert, R.; Peeters, G.; Hanset, R., 1981 : Plasma growth hormone (GH) level in double-muscled and conventional bulls during the first year of life. Z. Tierzüchtg. Züchtungsbiol. 98, 187.

MUNRO, H.N., 1964: General aspects of the regulation of protein metabolism by diet and hormones. In: Munro, H. N. (Ed.), Mammalian protein metabolism. Vol 1, p 382. New York, Academic Press.

Randle, P. J.; Garland, P. B.; Hales, C. N.; Newholmes, E. A.; Denton, R. M.; Pogson, C. I., 1966: Interactions of metabolim and the physiological role of insulin. Rec. Progr. Horm. Rec. 22,1.

RogDAKIS, E.; ENSINGER, U.; FABER, H. V., 1979: Hormonspiegel im Plasma und Enzymaktivitäten im Fettgewebe von Pietrain- und Edelschweinen. Z. Tierzüchtg. Züchtungsbiol. 96, 108.

SALTER, J.; BeST, C. H., 1953: Insulin as a growth hormone. Brit. Med. J. 2, 353.

SizonenKo, P. C., 1978: Endocrinological control of growth. Postgraduate Med. J. 54, Suppl. 1, 91.

Thorel., J.I.; Johansson, B. G., 1971: Enzymatic iodination of polypeptides with's I to high specific activity. Bioch. Biophys. Acta, 251, 363.

TRENKLE, A., 1970: Plasma levels of growth hormone, insulin and plasma protein bound iodine in finishing cattle. J. Anim. Sci. 31, 389.

TrenkLe, A.; IRvin, R., 1970: Correlations of plasma hormone levels with growth and carcass characteristics of cattle. Growth 34, 313. 
Trinki.f. A.: Torkt. I). (;., 1978: Relationships of some endocrine measurements to growth and carcass composition of cattle. J. Anim. Sci. 46, 1604.

TURNF. M. R. MUNDAY, K. A., 1976: Hormonal control of muscle growth. In: ListF.R, D.; Rhodfs, D. N.; Fowt.F. U. R.: Fut.t.f., M. F. (ED.), Meat animals: growth and productivity, Chap. 12, p. 197. Nen York: Plenum Press.

VAn IVYr, J. J.; Undfrwoov, L. E.; Hint7, R. L.; Cl.emmons, D. R.; Voina, S. J.; Weaver, R. P., 1974: The somatomedins: a family of insulinlike hormones under growth hormone control. Recent Progr. Horm. Res 30, 259.

WUOd, J. D.; (;RfGORY, N. G.; HALI. G. M.; LISTF, D., 1977: Fat mobillization in Pietrain and L.arge W'hite pigs. Brit. J. Nutr. 37, 167.

Wool, I. G.; Stirewat.t, W. S.; Kurihara, K.; Low, R. B.; Bailey, P.; Oyer, D., 1968: Mode of action of insulin in the regulation of protcin biosynthesis in muscle. Rec. Progr. Horm. Res. $24,139$. York, D. A., 1979: The characteristics of genetically obese mutants. In: Festing, M. F.W., (Ed.), Animal model of obesity. The MacMillan Press Lid.

YuUng, J. W.: Utcherf, E. O.; TrFnkl., A.: JACOBson, N. L., 1970: Effect of age on glucose reducing sugars and plasma insulin in blood of milk fed calves. J. Nutr. 100, 1267.

Authors's address: Dr. C. Mıchaux, Department of Genetics, Faculté de Médecine Vétérinaire, Rue des Vétérinaires, 45, B-1070 Bruxelles 